\title{
The First Case of Otomyiasis Caused by Sarcophaga spp. (Diptera; Sarcophagidae) Larvae in a Goose in the World
}

\section{Dünyada İlk Kez Bir Kazda Sarcophaga spp. Larvaları Tarafindan Oluşturulan}

\author{
Otomyiazis Olgusu
}

Osman Selçuk Aldemir, Emrah Şimşek, Adnan Ayan

Department of Parasitology, Adnan Menderes University Faculty of Veterinary Science, Aydın, Turkey

\begin{abstract}
Otomyiasis was diagnosed in the right ear of a 3-month-old goose. Twenty-three of 25 larvae were in the meatus acusticus externus, and 2 larvae were under the skin. The larvae were in the third larval stage of Sarcophaga spp. by microscopic examination. A case of otomyiasis was reported in goose for the first time in the world on the basis of morphological characteristics (macroscopic and microscopic evaluation) in this communication. (Turkiye Parazitol Derg 2014; 38: 211-3)
\end{abstract}

Key Words: Sarcophaga spp., otomyiasis, goose

Received: 07.04.2014

Accepted: 09.04.2014

\section{ÖZET}

Yaklaşık 3 aylık bir kazın sağ kulağında otomyiazis saptanmıştır. Yirmi üç larva meatus acusticus externusta, 2 tanesi ise deri altında olmak üzere toplam 25 larvaya rastlanılmıştır. Bu larvalar bulundukları yerlerden toplandıktan sonra ağız parçaları ve posterior stigmalar disekte edilmiştir. Myiasis bölgesinden elde edilen larvaların mikroskobik incelenmesi sonucu Sarcophaga spp. 3. dönem larva oldukları saptanmıştır. Kazlarda Sarcophaga spp. larvaları tarafından oluşturulan otomyiazis olgusu Dünyada ilk kez bildirilmiştir. (Turkiye Parazitol Derg 2014; 38: 211-3)

Anahtar Sözcükler: Sarcophaga spp, otomyiazis, kaz

Geliş Tarihi: 07.04.2014

Kabul Tarihi: 09.04.2014

\section{INTRODUCTION}

Myiases are serious health problems not only in animals but also in man, especially in subtropical and tropical areas (1, 2). There are several categories of myiasis, as in other forms of parasitism. Obligatory myiasis depends on the insect and a period of parasitism before it can complete its life cycle. If a normally free-living maggot accidentally gains entrance into a host, it becomes accidental myiasis. Such cases are also called pseudomyiasis. Pseudomyiasis usually involves muscoid flies, such as Musca domestica and Fannia spp. (3).
Flies causing myiasis belong to the family of Diptera, and its seven different families (Calliphoridae, Sarcophagidae, Oestridae, Hypodermatidae, Gasterophylidae, Cuterebridae, Fanniidae, and Muscidae) have been known to invade skin and body cavities, such as the nasal fossae and ears and cause odoriferous discharges. The medical interest of the family is principally, as myiasis producers, Musca, Auchmeromyia, Cochliomyia, Chrysomya, Fannia, Cordylobia, Lucilia, Sarcophaga, and Calliphora.

Orotracheal myiasis in an old man was described by Çiftcioğlu et al. (4) in Turkey. Traumatic myiasis (but no oto-

Address for Correspondence / Yazışma Adresi: Dr. Osman Selçuk Aldemir, Adnan Menderes Üniversitesi Veteriner Fakültesi, Parazitoloji Anabilim Dalı, Aydın, Turkey. Phone: +90 2562470700 E-mail: oselcuk9@hotmail.com DOI:10.5152/tpd.2014.3591

(C) Copyright 2014 Turkish Society for Parasitology - Available online at www.tparazitolderg.org

OTelif hakkı 2014 Türkiye Parazitoloji Derneği - Makale metnine www.tparazitolderg.org web sayfasından ulaşılabilir. 


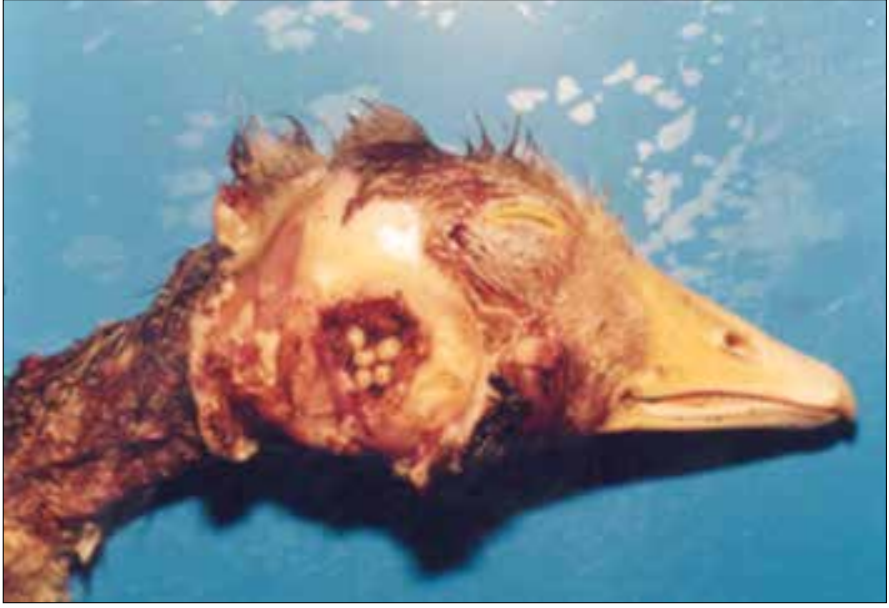

Figure 1. The presence of larvae in the meatus acusticus

myiasis) caused by W. magnifica and Lucilia spp. in geese was described by Farkas et al. (5) in Hungary. Gingival myiasis caused by Diptera (Calliphoridae) was described by Gürsel et al. (6) in Turkey.

Although many different cases of myiasis caused by Sarcophaga spp. larvae were reported in man (3), there has not been any report in animals. Therefore, otomyiasis was reported in goose for the first time in the world on the basis of morphological characteristics (macroscopic and microscopic evaluation) in this communication.

\section{CASE REPORT}

A 3-month-old goose was referred with a complaint of an ear wound. A total of 25 larvae were collected from the external and middle ear canal.

\section{Clinical Examination}

The external and middle ear canal were probed carefully, and the larvae were grasped and removed with gentle force. In the right ear of the goose was diagnosed in the ventral aspects of the wound approximately $1 \mathrm{~cm}$ in diameter and $0.5 \mathrm{~cm}$ in depth showing a hemorrhagic appearance with a pungent smell and containing crusted areas. In this area, a total of 25 larvae were collected; 23 were alive and obtained from the external and middle ear canal. The remainder $(n=2)$ were non-motile and seen in the submandibular and ventral region of the neck (Figure 1). The larvae were typical maggot form with a pointed anterior and truncate posterior end.

\section{Diagnosis}

Description of larvae was carried out by the method of Jimenez (7), which was slightly modified as follows: the larvae were placed live into Kahle's fluid (6 parts of 35\% formalin, 15 parts of $95 \%$ ethanol, 2 parts of glacial acetic acid, 30 parts of distilled water) for fixation up to 24 hours, rinsed, and stored in $80 \%$ ethanol. For the detection of mouthparts and spiracle characteristics, microscopic examination was done. Prior to the examination, the material was cleared in $\mathrm{KOH}$ at room temperature at least for 12 hours. In order to dehydrate, the larvae were transferred to absolute alcohol, and then, the dissection was carried out to obtain mouthparts and posterior spiracles. The flat area of the posterior spiracular disc was

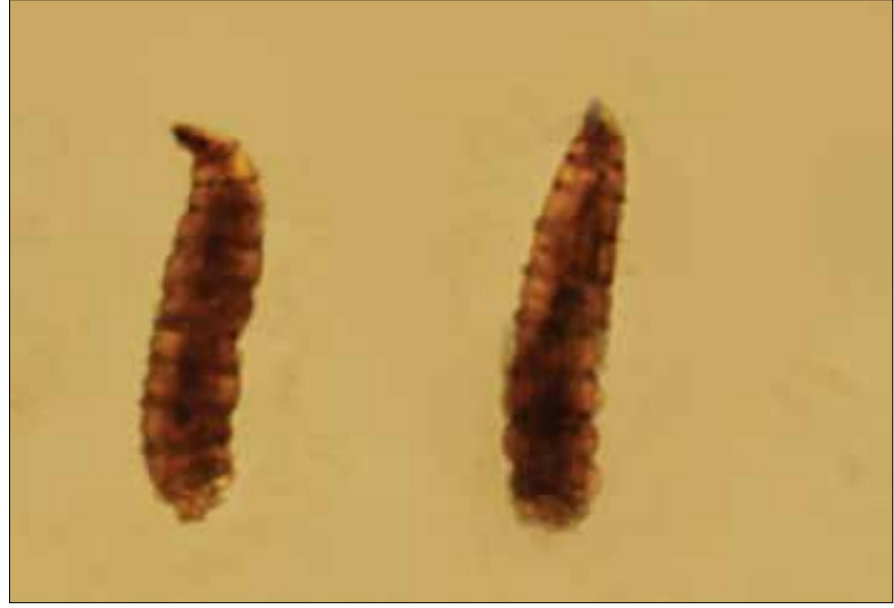

Figure 2. Sarcophaga spp

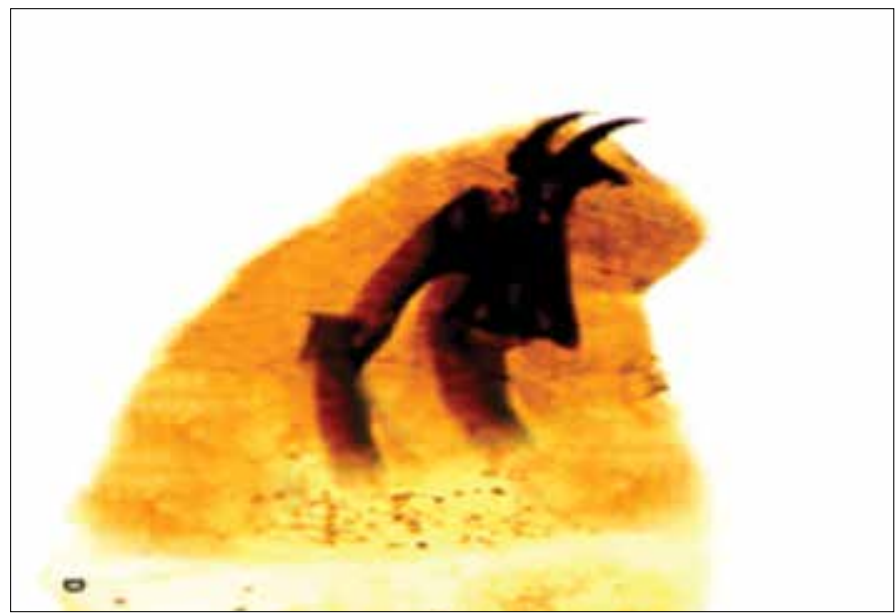

Figure 3. Sarcophaga spp. mouthparts of third larval-stage larvae in lateral view

cut off and mounted by Canadian balm and then identified as L3 stage of Sarcophaga spp. by light microscopy (Figure 2).

The body of larva comprised 12 segments; a small head segment, incompletely divided from a prothoracic segment, followed by a mesothoracic, a metathoracic, and eight abdominal segments. There was no clear distinction between the thorax and abdomen. The head segment was divided by a ventral furrow into left and right cephalic lobes, with the mouth opening at the base of furrow. The parts of the mouth consisted of a pair of mouth-hooks and associated sclerites for the attachment of muscles, collectively known as the cephalopharyngeal skeleton. The dorsal cornu of the cephalopharyngeal skeleton split into two branches (Figure 3). Larva did not have true segmental appendages and were thus technically legless.

There were a pair of anterior spiracles on the prothoracic segment and a pair of caudal or posterior spiracles on the $12^{\text {th }}$-i.e., terminal-segment. The anterior spiracles protruded through the body wall and divided into a fan-shaped series of finger-like lobes, each ending in a small aperture. The posterior spiracles comprised a pair of sclerotized plates, either set flat on the body cuticle of the last abdominal segment (Figure 4). 


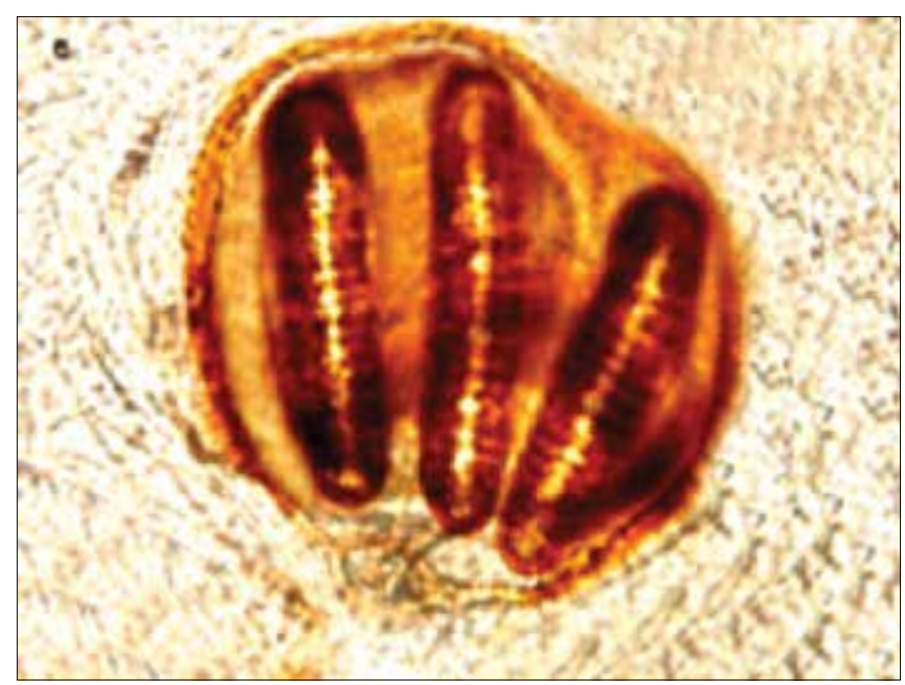

Figure 4. Sarcophaga spp. posterior spiracles of third larval-stage larvae

These characteristics findings provided very useful taxonomic characteristics, which led us to conclude that the larvae belonged to the Sarcophagidae family.

\section{DISCUSSION}

Myiasis is an uncommon condition produced by the invasion of tissues by the larvae of flies. This phenomenon has mainly been reported in underdeveloped and developing countries or in individuals living in rural areas. It has been reported that the most important myiasis in human tissues and vertebrates belongs to the families Calliphoridae and Sarcophagidae $(8,9)$. Most cases have been reported as occurring in the summer when the flies hatch. Individuals in colder climates are much less affected as compared to those living in tropical and subtropical areas (8).

\section{CONCLUSION}

The first case of otomyiasis in goose in the world was reported on the basis of morphological characteristics (macroscopic and microscopic evaluation).

Peer-review: Externally peer-reviewed.

Author Contributions: Concept - O.S.A., E.Ş., A.A.; Design O.S.A., E.Ş., A.A.; Supervision - O.S.A., E.Ş., A.A.; Funding -
O.S.A., E.Ş., A.A.; Materials - O.S.A., E.Ş., A.A.; Data Collection and/or Processing - O.S.A., E.Ş., A.A.; Analysis and/or Interpretation - O.S.A., E.Ş., A.A.; Literature Review - O.S.A., E.Ş., A.A.; Writing - O.S.A., E.Ş., A.A.; Critical Review - O.S.A., E.Ş., A.A.; Other - O.S.A., E.Ş., A.A.

Conflict of Interest: No conflict of interest was declared by the authors.

Financial Disclosure: The authors declared that this case has received no financial support.

Hakem değerlendirmesi: Dış bağımsız.

Yazar Katkıları: Fikir - O.S.A., E.Ş., A.A.; Tasarım - O.S.A., E.Ş., A.A.; Denetleme - O.S.A., E.Ş., A.A.; Kaynaklar - O.S.A., E.Ş., A.A.; Malzemeler - O.S.A., E.Ş., A.A.; Veri Toplanması ve/veya İşlemesi - O.S.A., E.Ş., A.A.; Analiz ve/veya Yorum - O.S.A., E.Ş., A.A.; Literatür Taraması - O.S.A., E.Ş., A.A.; Yazıyı Yazan - O.S.A., E.Ş., A.A.; Eleştirel İnceleme - O.S.A., E.Ş., A.A.; Diğer - O.S.A., E.Ş., A.A.

Çıkar Çatışması: Yazarlar çıkar çatışması bildirmemişlerdir.

Finansal Destek: Yazarlar bu olgu için finansal destek almadıklarını beyan etmişlerdir.

\section{REFERENCES}

1. Hall M, Wall R. Myiasis of human and domestic animals. Adv Parasitol 1995; 35: 257-334. [CrossRef]

2. Sherman RA. Wound myiasis in urban and suburban United States. Arch Intern Med 2000; 160: 2004-14. [CrossRef]

3. Kettle DS. Medical and Veterinary Entomology. University press; Cambridge. 1984.

4. Ciftcioğlu N, Altintaş S, Haberal M. A case of human orotracheal myiasis caused by Wohlfartia magnifica. Parasitol Res 1997; 83: 34-6.

5. Farkas R. Myiasis caused by the flesh fly Wohlfartia magnifica. Magy Allotorv Lapja 1996; 51: 341-51.

6. Gursel M, Aldemir OS, Ozgur Z, Ataoglu T. A rare case of gingival myiasis caused by diptera (Calliphoridae). J Clin Periodontol 2002; 29: 777-80. [CrossRef]

7. Jimenez JM. Preparation of Dipteran larvae for scanning electron microscopy with special reference to myiasigen Dipteran species. Scanning Microscopy 1989; 3: 387-90.

8. Smith KGV. A manual of forensic entomology. British Museum (Natural History), London, and Cornell University Press; 1986. Ithaca. New York. 205 p.

9. Zumpt F, Stimie M. Strobiloestrus clarkii (clark) reared for the first time from the african steenbok (raphicerus campestris (thunberg)) (diptera: oestridae). Z Parasitenkd 1965; 25: 339-41. [CrossRef] 